Check for updates

Cite this: RSC Adv., 2019, 9, 3704

Received 28th November 2018 Accepted 13th January 2019

DOI: $10.1039 / \mathrm{c} 8 \mathrm{ra09788g}$

rsc.li/rsc-advances

\section{Graphene oxide decorated with zinc oxide nanoflower, silver and titanium dioxide nanoparticles: fabrication, characterization, DNA interaction, and antibacterial activity $\uparrow$}

\author{
Nagi El-Shafai, ab Mohamed E. El-Khouly, (DD *cd Maged El-Kemary, bc \\ Mohamed Ramadan, ${ }^{a}$ Ibrahim Eldesoukey ${ }^{e}$ and Mamdouh Masoud ${ }^{a}$
}

\begin{abstract}
The fabrication, characterization, and antibacterial activity of novel nanocomposites based on graphene oxide (GO) nanosheets decorated with silver, titanium dioxide nanoparticles, and zinc oxide nanoflowers were examined. The fabricated nanocomposites were characterized by various techniques including $X$ ray diffraction, ultraviolet-visible light absorption and fluorescence spectroscopy, Brunauer-EmmettTeller theory analysis, Fourier transform infrared, and scanning electron microscopy. The antibacterial activity of the GO-metal oxide nanocomposites against two Gram-positive and two Gram-negative bacteria was examined by using the standard counting plate methodology. The results showed that the fabricated nanocomposites on the surface of GO could inhibit the growth of microbial adhered cells, and consequently prevent the process of biofilm formation in food packaging and medical devices. To confirm the antibacterial activity of the examined GO-nanocomposites, we examined their interactions with bovine serum albumin (BSA) and circulating tumor DNA (ctDNA) by steady-state fluorescence spectroscopy. Upon addition of different amounts of fabricated GO-nanocomposites, the fluorescence intensities of the singlet states of BSA and ctDNA were considerably quenched. The higher quenching was observed in the case of $\mathrm{GO}-\mathrm{Ag}-\mathrm{TiO}_{2} \mathrm{QZnO}$ nanocomposite compared with other control composites.
\end{abstract}

\section{Introduction}

Microorganisms, such as bacteria communities, are found in many different environments (water, soil, skin, and air), and can anchor on various surfaces to produce biofilms that often show high resistance to antimicrobial drugs. ${ }^{1,2}$ In the food industry, the presence of biofilms leads to severe hygiene problems, economic losses, food spoilage, and even serious infectious diseases. ${ }^{2-5}$ Escherichia coli (E. coli) is a bacterial commensal microflora in the intestinal tract of a number of animals, including humans. Although most strains of E. coli are harmless, some are able to cause diseases in humans as well as in mammals and birds. ${ }^{6}$ Staphylococcus aureus (S. aureus) is a microorganism that is present as a commensal on the skin, the nose, and mucous membranes of healthy humans and

${ }^{a}$ Department of Chemistry, Faculty of Science, Alexandria University, Egypt ${ }^{b}$ Institute of Nanoscience and Nanotechnology, Kafrelsheikh University, Egypt 'Department of Chemistry, Faculty of Science, Kafrelsheikh University, Egypt

${ }^{d}$ Institute of Basic and Applied Sciences, Egypt-Japan Institute of Science and Technology, Alexandria, Egypt.E-mail: mohamed.elkhouly@ejust.edu.eg

${ }^{e}$ Department of Bacteriology, Mycology and Immunology, Faculty of Veterinary Medicine, Kafrelsheikh University, Egypt

$\dagger$ Electronic supplementary information (ESI) available. See DOI: $10.1039 / \mathrm{c} 8 \mathrm{ra} 09788 \mathrm{~g}$ animals. However, it is also an opportunistic pathogen that can cause multiple infectious diseases of varying severity. ${ }^{7}$ Pasteurella multocida (P. multocida), a Gram-negative coccobacillus, is a member of the normal flora of the upper respiratory and gastrointestinal tract of many domestic and wild animals. ${ }^{8}$ Bacillus anthracoides (B. anthracoides) is a group of widely distributed bacteria in nature. Most strains are nonpathogenic; however, some may cause serious infectious diseases in humans and animals.

The resistance of bacteria and fungi to traditional antibiotics is an increasing problem, and the identification and treatment of antibiotic-resistant microorganisms is difficult and costly., Furthermore, complications associated with antibiotic-resistant bacterial infections are a cause of high morbidity and mortality, with antibiotic resistance leading to challenges such as inhibition of drug uptake, enzymatic modification of antibiotics, and alteration of target molecules. Therefore, the development of new antimicrobial drugs based on nanoparticles for the treatment of resistant pathogens may have many advantages, including low toxicity and reduced cost compared with conventional antibiotics. ${ }^{11-13}$ Several studies have examined the antibacterial activity of nanoparticles against both Grampositive and Gram-negative bacteria, such as iron oxide $\left(\mathrm{Fe}_{3} \mathrm{O}_{4}\right)$, zinc oxide $(\mathrm{ZnO}),{ }^{14}$ copper oxide $(\mathrm{CuO}),{ }^{15}$ titanium oxide 
$\left(\mathrm{TiO}_{2}\right),{ }^{16}$ silver $(\mathrm{Ag}),{ }^{17}$ magnesium oxide $(\mathrm{MgO}),{ }^{18}$ graphene oxide (GO), reduced graphene (rGO), ${ }^{19}$ nitric oxide (NO) nanoparticles, ${ }^{20,21}$ and carbon nanotubes and graphene, which are chemically modified to graphene oxide ${ }^{22}$ and able to form stable dispersions in water. ${ }^{23-27}$

Over recent decades, silver nanoparticles (AgNPs) have attracted considerable attention in terms of their antimicrobial, medical, and chemical applications due to their high resistance to oxidation and high thermal conductivity. ${ }^{25-32}$ Furthermore, AgNPs can damage the bacterial cell membrane, disturb DNA replication, and lead to increased permeability and ultimately to cell death. ${ }^{33-35}$ The grain size of AgNPs is an important factor in this process. ${ }^{36-38}$

Recently, the antibacterial activity of graphene-based nanocomposites has attracted much attention due to the unique properties of graphenes; e.g., their high theoretical specific surface. ${ }^{39-41}$ In this study, we report the fabrication of novel nanocomposites, namely $\mathrm{GO}$ decorated with $\mathrm{Ag}$, $\mathrm{TiO}_{2}$, and $\mathrm{ZnO}$ nanoflowers (GO-Ag-TiO $\left.\mathrm{G}_{2} @ \mathrm{ZnO}\right)$. For comparison, $\mathrm{GO}-\mathrm{Ag}$ and GO-TiO ${ }_{2} @ Z n O$ have been fabricated and characterized. Several considerations led us to design the $\mathrm{GO}-\mathrm{Ag}-\mathrm{TiO}_{2} @ \mathrm{ZnO}$ nanocomposite: (1) GO has the advantages of ease of fabrication, ease of processing, and economic production, with large scale and low cost; (2) GO has mild cytotoxicity to mammalian cells in low dose; (3) GO exhibits high antibacterial efficiency in its ability to damage the cell membranes via the generation of reactive oxygen species (ROS) and has exceptionally sharp edges; (4) Ag nanoparticles can consistently cause bacterial cell membrane damage, disturbing DNA replication, and leading to increased permeability and ultimately cell death; ${ }^{42-46}(5) \mathrm{TiO}_{2}$ could be used for the killing or growth inhibition of bacteria due to its strong oxidation activity and super hydrophilicity; (6) ZnO exhibits antibacterial activity through generation of ROS and/or accumulation of NPs in the cytoplasm that lead to the interruption and inhibition of membrane and cellular tasks.

In order to confirm the antibacterial activity of the fabricated nanocomposites, the fluorescence quenching of bovine serum albumin (BSA) and circulating tumor DNA (ctDNA) were examined using the steady-state fluorescence technique. The results showed the excellent ability of the fabricated nanocomposite (GO-Ag- $\left.-\mathrm{TiO}_{2} @ \mathrm{ZnO}\right)$ against growth of bacteria by destroying the DNA bacteria; this was confirmed with both Gram-positive and Gram-negative bacteria.

\section{Experimental section}

\subsection{Chemicals and materials}

Silver nitrate, zinc acetate, titanium(Iv) $n$-isobutoxide, graphite, potassium hydroxide, and ethanol were purchased from SigmaAldrich. All used chemicals in this study were of reagent grade and were used without any further purification.

2.1.1. Synthesis of graphene oxide nanostructure. A modified Hummers and Offeman's method was used to fabricate the GP nanosheet from natural graphite powder. ${ }^{47,48} 8 \mathrm{~g}$ of graphite powder (Sigma-Aldrich) and a stoichiometric amount of $\mathrm{NH}_{4} \mathrm{NO}_{3}$ were added to $368 \mathrm{ml}$ of $98 \%(\mathrm{w} / \mathrm{w}) \mathrm{H}_{2} \mathrm{SO}_{4}$ in an ice bath. $\mathrm{KMnO}_{4}$ was slowly added to the mixture with continuous stirring until the solution turned green. $640 \mathrm{ml}$ of pure water was added, and stirring continued at $90{ }^{\circ} \mathrm{C}$ until the solution yielded a brown precipitate. Finally, $\mathrm{H}_{2} \mathrm{O}_{2}(30 \%)$ was added slowly until the solution turned a yellow color. The solid was removed by filtration, washed with $10 \% \mathrm{HCl}$ aqueous solution to remove metal ions, and washed several times with water. The $\mathrm{GO}$ obtained was dried at $45^{\circ} \mathrm{C}$.

2.1.2. Synthesis of silver nanoparticles. In a three-necked glass flask, $1 \mathrm{mM}$ of silver nitrate was dissolved in $100 \mathrm{ml}$ deionized water (DW) under constant stirring and heating to $60{ }^{\circ} \mathrm{C}$, then $1 \mathrm{mM}$ of trisodium citrate was added as a stabilizing agent under stirring. 10\% hydrazine hydrochloride as a reducing agent was added slowly with stirring, until a paleyellow suspension formed, then the crystalline structure was centrifuged and washed several times with ethanol and water, and dried at $50{ }^{\circ} \mathrm{C}$ before undergoing analysis.

2.1.3. Synthesis of titanium dioxide. $6 \mathrm{ml}$ of titanium(Iv) $n$ isobutoxide $98 \%$ was added dropwise to a mixture of ethanolwater $(4: 1)$ at $90{ }^{\circ} \mathrm{C}$. After undergoing reflux for $2 \mathrm{~h}$ at $90{ }^{\circ} \mathrm{C}$, a white precipitate was produced. The obtained precipitate was centrifuged at $6000 \mathrm{rpm}$, and then washed several times with DW and ethanol, then dried at $50{ }^{\circ} \mathrm{C}$ and calcined at $470{ }^{\circ} \mathrm{C}$ for $2 \mathrm{~h}^{49}$

2.1.4. Synthesis of GO-Ag nanocomposite. $0.04 \mathrm{~g}$ of GO nanosheet was dispersed in $100 \mathrm{ml}$ water for $30 \mathrm{~min}$ by ultrasonication, and then heated to $60{ }^{\circ} \mathrm{C}$. A solution of the fabricated silver NPs described previously was added dropwise, and a deep brown precipitate was formed. The precipitate was collected by centrifugation, then washed with $\mathrm{H}_{2} \mathrm{O}$ and ethanol, and the product was dried under vacuum at $45{ }^{\circ} \mathrm{C}$.

2.1.5. Synthesis of GO- $\mathrm{TiO}_{2} @ \mathrm{ZnO}$ nanocomposite. $0.04 \mathrm{~g}$ of GO nanostructure was dispersed in $100 \mathrm{ml}$ water for $30 \mathrm{~min}$ by ultrasonication, and $100 \mathrm{ml}$ aqueous solution of $0.2 \mathrm{M}$ $\mathrm{Zn}\left(\mathrm{CH}_{3} \mathrm{COOH}\right)_{2} \cdot 2 \mathrm{H}_{2} \mathrm{O}$ was added slowly with stirring for $15 \mathrm{~min}$. This mixture was then added dropwise to $1 \mathrm{M}$ of a hot solution of $\mathrm{KOH}$ in ethanol. The resultant mixture was stirred for $3 \mathrm{~h}$ at $100^{\circ} \mathrm{C}$, and $0.5 \mathrm{~g}$ of $\mathrm{TiO}_{2} \mathrm{NPs}$ was added to the mixture with vigorous stirring for $3 \mathrm{~h}$. The resulting mixture was ultrasonication for $2 \mathrm{~h}$, then the product was centrifuged and washed with water and methanol several times. GO-ZnO$\mathrm{TiO}_{2} @ A g$ nanocomposite was obtained after drying at $45{ }^{\circ} \mathrm{C}$.

2.1.6. Synthesis of $\mathrm{GO}-\mathrm{Ag}-\mathrm{TiO}_{2} @ \mathrm{ZnO}$ nanocomposite. $0.04 \mathrm{~g}$ of GO nanostructure was dispersed in $100 \mathrm{ml}$ water for $30 \mathrm{~min}$ by ultrasonication and $100 \mathrm{ml}$ aqueous solution of $0.2 \mathrm{M}$ $\mathrm{Zn}\left(\mathrm{CH}_{3} \mathrm{COOH}\right)_{2} \cdot 2 \mathrm{H}_{2} \mathrm{O}$ was added slowly with stirring for $15 \mathrm{~min}$. This mixture was added dropwise to $1 \mathrm{M}$ of a hot solution of $\mathrm{KOH}$ in ethanol. The resultant mixture was stirred for $3 \mathrm{~h}$ at $100{ }^{\circ} \mathrm{C}$, then $0.5 \mathrm{~g}$ of both $\mathrm{Ag} \mathrm{NPs}$ and $\mathrm{TiO}_{2} \mathrm{NPs}$ were added to the mixture with vigorous stirring for $3 \mathrm{~h}$. The resultant mixture underwent ultrasonication for $2 \mathrm{~h}$, then the product was centrifuged and washed with water and methanol several times. GO-ZnO$\mathrm{TiO}_{2} @ A g$ nanocomposite was obtained after drying at $45^{\circ} \mathrm{C}$.

\subsection{Characterization techniques}

Ultraviolet-visible (UV-vis) absorption spectra were measured using a Shimadzu UV-2450 spectrophotometer. Fluorescence spectra were recorded using a Shimadzu RF-5301PC 
spectrofluorometer. Fourier-transform infrared (FT-IR) spectra were recorded with a JASCO spectrometer 4100, using the $\mathrm{KBr}$ pellet technique. X-ray diffraction (XRD) measurements were reported using a Shimadzu 6000-XRD, X-ray diffractometer using $\mathrm{Cu}-\mathrm{K} \alpha$ radiation $\left(\lambda \frac{1}{4} 1.54065 \AA\right)$. Transmission electron microscopy (TEM) images were captured by a JEOL 2010 microscope operating at an accelerating voltage of $200 \mathrm{kV}$, and the morphology of the surface was estimated with scanning electron microscopy (SEM) using a JEOL (JSMIT100) instrument operating at $30 \mathrm{kV}$. Zeta potential results were carried out on Brookhaven zeta potential/particle size analyzer, and the surface area and pore size distribution were determined through Brunauer-Emmett-Teller (BET) analysis using Nova LX. $^{3}$

\subsection{Antimicrobial activity}

2.3.1. Preparation of microbiological cultures. For antibacterial assessment, $S$. aureus and $B$. anthracoides were selected as representative Gram-positive bacteria. E. coli, P. multocida, and $P$. multocida were selected as representative Gram-negative bacteria. All bacterial strains were obtained from the Central Diagnostic and Research Laboratory at the Faculty of Veterinary Medicine, Kafrelsheikh University, Egypt. At first, the tested bacterial strains were cultured on blood agar media (Oxoid) at $37{ }^{\circ} \mathrm{C}$ for $24 \mathrm{~h}$. The strains of $S$. aureus, B. anthracoides, and $E$. coli were grown in Mueller-Hinton broth (Oxoid) media, while $P$. multocida was grown on tryptic soya broth (Oxoid). Briefly, $10 \mathrm{ml}$ of the appropriate broth was inoculated with a single colony of each bacteria strain and incubated at $37^{\circ} \mathrm{C}$ for 12 h. $^{50}$

2.3.2. Zones of inhibition. The disk diffusion (Kirby-Bauer) method was used to evaluate the antimicrobial activity of each nanoparticle compound. Bacterial cultures were diluted in the Mueller-Hinton broth, and achieved an optical density corresponding to 0.5 MacFarland standards, in which the concentration of bacteria was $1.5 \times 10^{8} \mathrm{CFU} \mathrm{ml}^{-1}$. The Mueller-Hinton agar medium (Oxoid) was prepared and sterilized at $121{ }^{\circ} \mathrm{C}$ in an autoclave, then about $15 \mathrm{ml}$ of the melted agar media was poured aseptically into each of the sterilized Petri plates and kept at room temperature for solidification. $100 \mu \mathrm{l}$ of the prepared bacterial cell suspension was pipetted and spread across the dried surface of the Muller Hinton agar. Sterile filter paper disks loaded with each nanoparticle (at a concentration of $0.005 \mathrm{~g} / 10 \mathrm{ml}$ ) were placed on the surface of the Mueller-Hilton agar plate using sterile forceps. The plates were incubated at $37^{\circ} \mathrm{C}$ for $24 \mathrm{~h}$. Following incubation, the zones of inhibition were measured in $\mathrm{mm}$ from four sides of each well to determine an average mean value. The presence of inhibition zones was measured by vernier caliper, and was recorded and considered as an indication for antibacterial activity. ${ }^{51,52}$

\section{Results and discussion}

\subsection{XRD analysis}

Fig. 1 shows the patterns of the pure graphite powder, GO, Ag, GO-Ag, GO- $\mathrm{TiO}_{2} @ \mathrm{ZnO}$ and $\mathrm{GO}-\mathrm{Ag}-\mathrm{TiO}_{2} @ \mathrm{ZnO}$

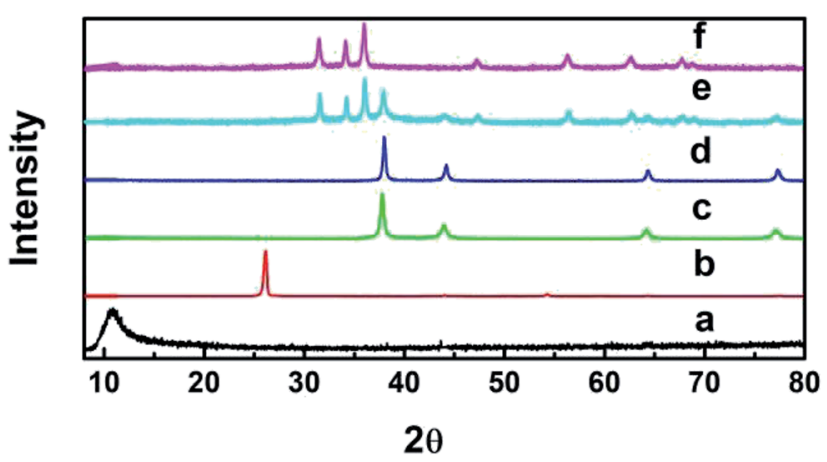

Fig. 1 XRD patterns of (a) GO, (b) graphite, (c) Ag, (d) GO-Ag, (e) GO$\mathrm{Ag}-\mathrm{TiO}_{2}\left(\mathrm{ZnO}\right.$, and (f) $\mathrm{GO}-\mathrm{TiO}_{2}(\mathrm{ZnO}$.

nanocomposites. The diffraction peaks of pure graphite powder and GO were recorded at $26^{\circ}$ and $10.9^{\circ}$, respectively, indicating the presence of oxygenated functional groups on carbon sheets of GO. ${ }^{53,54} \mathrm{Ag}$ NPs exhibited four peaks at $2 \theta=38.18^{\circ}, 44.25^{\circ}$, $64.72^{\circ}$, and $77.4^{\circ}$ that were attributed to the (111), (200), (220), and (311) crystalline planes. ${ }^{55,56}$ The presence of $\mathrm{Ag}$ nanoparticles over the GO surface in the nanocomposite (GO-Ag) was confirmed by recording peaks at $2 \theta=37.7^{\circ}, 44.3^{\circ}, 64.0^{\circ}$, and $77.0^{\circ} .{ }^{57,58} \mathrm{GO}^{-\mathrm{TiO}_{2}}$ @ZnO nanocomposite showed the characteristic peaks of $\mathrm{ZnP}$ nanoparticles at $31.67^{\circ}, 34.31^{\circ}, 36.1^{\circ}$, $56.5^{\circ}, 62.7^{\circ}$, and $67.9^{\circ},{ }^{59}$ while the $\mathrm{TiO}_{2}$ pattern showed values for the diffraction peak at $25^{\circ}$ and $47.59^{\circ} .{ }^{60}$ The slight shift to the lower region side might be due to the loading of $\mathrm{TiO}_{2}$ and

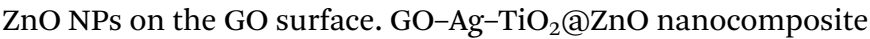
showed a sharp highly intensive peak at $37.8^{\circ}, 44^{\circ}, 64.2^{\circ}$, and $77.2^{\circ}$ (for $\mathrm{Ag}$ ), $47.3^{\circ}$ (for $\mathrm{TiO}_{2}$ ), and $31.67^{\circ}, 34.31^{\circ}, 36.1^{\circ}, 56.39^{\circ}$, $62.7^{\circ}$, and $67.9^{\circ}$ (for $\mathrm{ZnO}$ ). These features suggest that the metal oxides $\left(\mathrm{ZnO}, \mathrm{TiO}_{2}\right)$ and $\mathrm{Ag}$ NPs are loaded on the GO surface. The absence of a typical peak for GO may be due to the disruption and good exfoliation of GO in the nanocomposites and/or the loading of metal oxide NPs into the surface of GO oxide.

The main diameter was calculated from Debye-Scherrer's ${ }^{\circledR}$ formula (eqn (1)):

$$
D=K \lambda / \beta \cos \theta
$$

where $K$ is a constant representing shape factor $(\sim 0.9), \lambda$ is the wavelength of the X-ray source (1.5405 $\AA$ ), $\beta$ is the full width at half maximum of the diffraction peak, and $\theta$ is the angular position of the peak. According to this equation, the average diameters of Ag NPs and GO-Ag were determined to be $~ 20-$ $30 \mathrm{~nm}$ and $58 \mathrm{~nm}$, respectively. In GO-TiO ${ }_{2} @ \mathrm{ZnO}$, the average diameters were found to be $\sim 48 \mathrm{~nm}$ (for $\mathrm{ZnO}$ ) and $\sim 35 \mathrm{~nm}$ (for $\mathrm{TiO}_{2}$ ). When turning to $\mathrm{GO}-\mathrm{Ag}-\mathrm{TiO}_{2} @ \mathrm{ZnO}$, the average diameters were determined to be $\sim 24-40 \mathrm{~nm}$ (for $\mathrm{Ag}$ ), $\sim 40-$ $58 \mathrm{~nm}$ (for $\mathrm{ZnO}$ ) and $\sim 24-40 \mathrm{~nm}$ (for $\mathrm{TiO}_{2}$ ). The results illustrate that the anchoring of GO with metal oxide NPs has little influence on the crystallite size of the phase structure of the metal oxide NPs. 

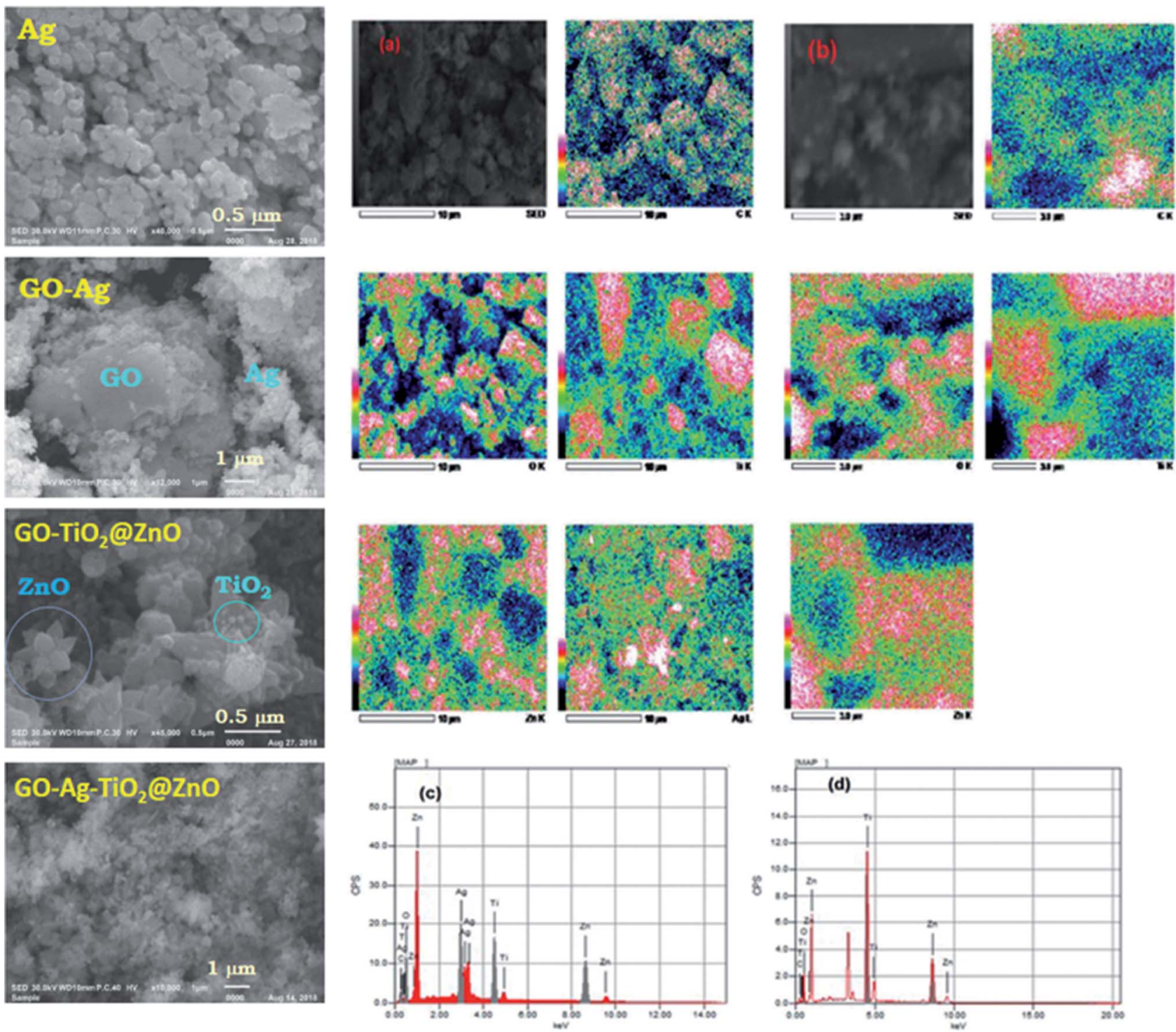

Fig. 2 (Left) SEM images of Ag, GO-Ag, GO-TiO $2\left(\mathrm{CnO}\right.$, and $\mathrm{GO}-\mathrm{Ag}-\mathrm{TiO}_{2} @ \mathrm{ZnO}$. (Right) SEM mapping of (a) GO-Ag-TiO 2 (anO and (b) GO$\mathrm{TiO}_{2} @ \mathrm{ZnO}$. (Bottom right) EDX of mapping image of (c) $\mathrm{GO}-\mathrm{Ag}-\mathrm{TiO}_{2}\left(\mathrm{ZnO}\right.$ and (d) $\mathrm{GO}-\mathrm{TiO}_{2}(\mathrm{ZnO}$.

\subsection{Scanning electron microscopy analysis}

SEM was performed with different magnifications to exhibit the morphology and energy-dispersive X-ray (EDX) of the metal oxides. Fig. 2 shows SEM images of $\mathrm{GO}, \mathrm{Ag}, \mathrm{GO}-\mathrm{Ag}, \mathrm{GO}-$ $\mathrm{TiO}_{2} @ \mathrm{ZnO}$, and GO-Ag- $\mathrm{TiO}_{2} @ \mathrm{ZnO}$ nanocomposites. As can be seen, the surface of the GO nanosheet was densely packed by metal oxides, indicating a good combination between GO and the metal oxide NPs. The GO nanosheets seem to act as bridges for the metal oxide entities. Ag NPs have a spherical morphology and are loaded successfully on the GO surface. As shown in Fig. 2c, the ZnO nanoflower appears clearly over the GO surface, while $\mathrm{TiO}_{2}$, with its spherical shape, is deposited on the $\mathrm{ZnO}$ nanoflower. This matching between the deposited $\mathrm{ZnO}$ and $\mathrm{TiO}_{2}$ over the GO surface confirmed by EDX formation of the GO-TiO ${ }_{2} @ \mathrm{ZnO}$ nanocomposite. The GO-Ag- $\mathrm{TiO}_{2} @ \mathrm{ZnO}$ nanocomposite presented as shown in Fig. 2, right. The GO-

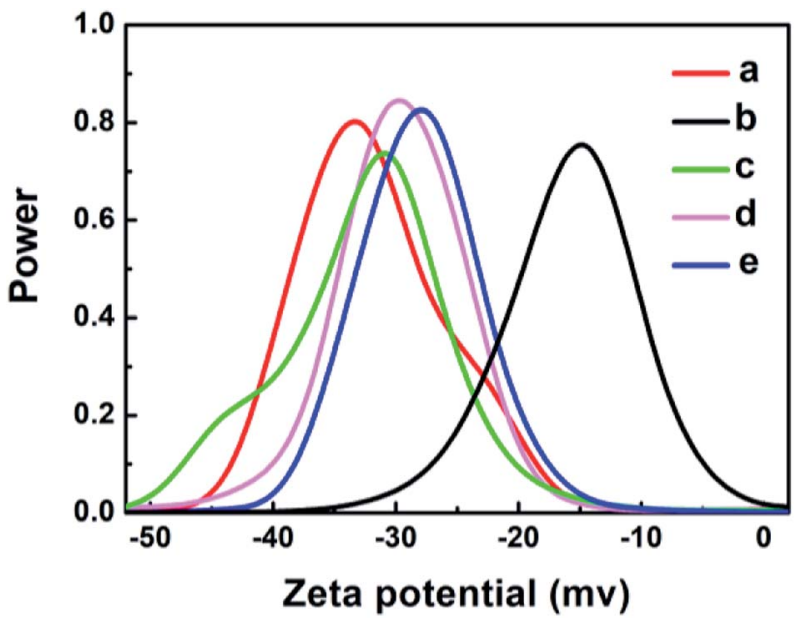

Fig. 3 Zeta potential graphs of: (a) GO, (b) Ag, (c) GO-Ag, (d) GO$\mathrm{TiO}_{2} \mathrm{aZnO}$, and (e) $\mathrm{GO}-\mathrm{Ag}-\mathrm{TiO}_{2} \mathrm{aZnO}$ in water. 


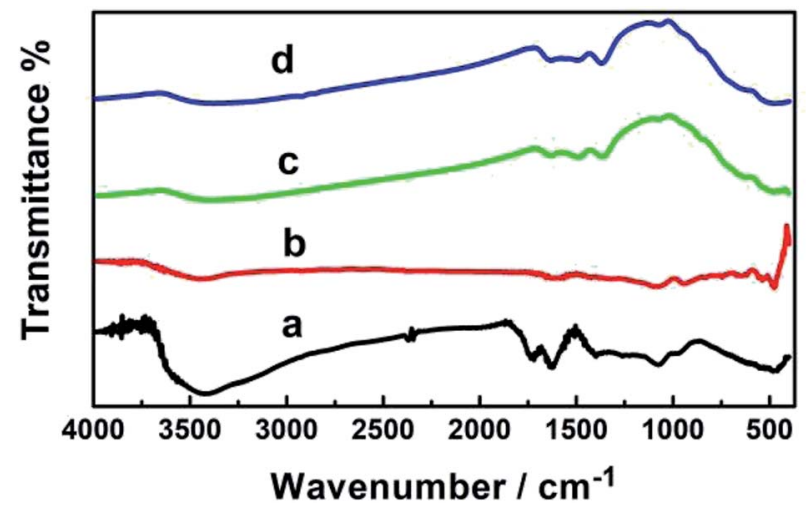

Fig. 4 FT-IR spectra of (a) GO, (b) GO-Ag, (c) GO-Ag-TiO $2 @ \mathrm{ZnO}$ and (d) $\mathrm{GO}-\mathrm{TiO}_{2} \mathrm{QZnO}$.

$\mathrm{TiO}_{2} @ \mathrm{ZnO}$ and $\mathrm{GO}-\mathrm{Ag}-\mathrm{TiO}_{2} @ \mathrm{ZnO}$ nanocomposites were analyzed using EDX with uniform particle morphology (Fig. 2, right).

\subsection{UV-vis absorption studies}

The absorption spectra of the examined nanocomposites and the control compounds were recorded in water at room temperature, as shown in Fig. S1.† The absorption spectrum of GO exhibited a strong absorption peak at $228 \mathrm{~nm}$ and shoulder at $300 \mathrm{~nm}$, which was assigned to the $\pi-\pi^{*}$ transitions of the aromatic $\mathrm{C}=\mathrm{C}$ bonds and $\mathrm{n}-\pi^{*}$ transitions of $\mathrm{C}=\mathrm{O}$ bonds, respectively. ${ }^{61,62} \mathrm{Ag}$ NPs and GO-Ag exhibited absorption bands at 440 and $420 \mathrm{~nm}$ that were assigned to the surface plasmon resonance of $\mathrm{Ag}$ NPs. This arises from the interaction of the incident light with the valence electrons of Ag NPs, leading to the oscillation of electrons along with the frequency of the electromagnetic source. ${ }^{63} \mathrm{GO}^{-\mathrm{TiO}_{2}} @ \mathrm{ZnO}$ exhibited absorption

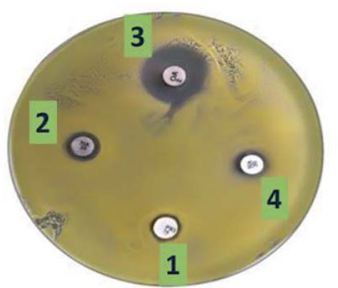

S. aureus

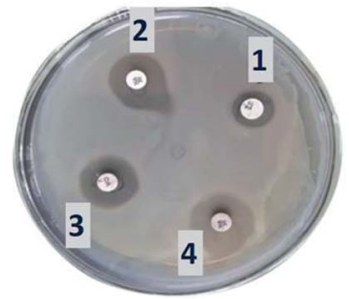

P. multocida

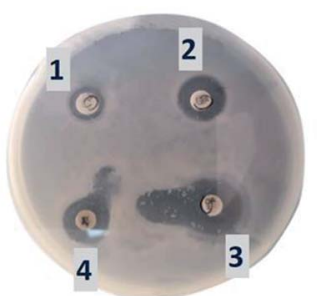

B. anthracoide

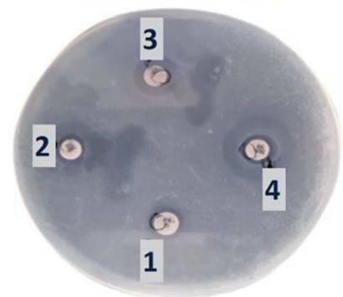

E. coli
Fig. 6 Effect of $\mathrm{Ag}$ (1), GO-Ag (2), $\mathrm{GO}-\mathrm{TiO}_{2} @ \mathrm{anO}$ (3), and $\mathrm{GO}-\mathrm{Ag}-$ $\mathrm{TiO}_{2} \mathrm{QZnO}$ (4) on Gram-positive and Gram-negative bacteria.

peaks at $365 \mathrm{~nm}(\mathrm{ZnO}), 244 \mathrm{~nm}\left(\mathrm{TiO}_{2}\right)$, and $290 \mathrm{~nm}$ (GO). For GO-Ag-TiO ${ }_{2} @ \mathrm{ZnO}$, absorption peaks were visible at $372 \mathrm{~nm}$ (ZnO), $437 \mathrm{~nm}(\mathrm{Ag}), 250 \mathrm{~nm}\left(\mathrm{TiO}_{2}\right)$, and $290 \mathrm{~nm}$ (GO). The energy band gap values of the nanocomposites were determined by the Tauc equation (eqn (2)): ${ }^{64,65}$

$$
\alpha h \nu=A\left(h \nu-E_{\mathrm{g}}\right)^{n}
$$

where $\alpha$ is the absorption coefficient, $h$ is Planck's constant, $\nu$ is the frequency of light, $A$ is a proportionality constant, $E_{\mathrm{g}}$ is the band gap and $n=1 / 2$ for the direct transitions. ${ }^{66}$ A plot of $(\alpha h \nu)^{2}$ versus $h \nu$ is shown in the inset of Fig. S2 in the ESI. $\dagger$ The linear portion of the curve is extrapolated to the $h \nu$ axis to determine
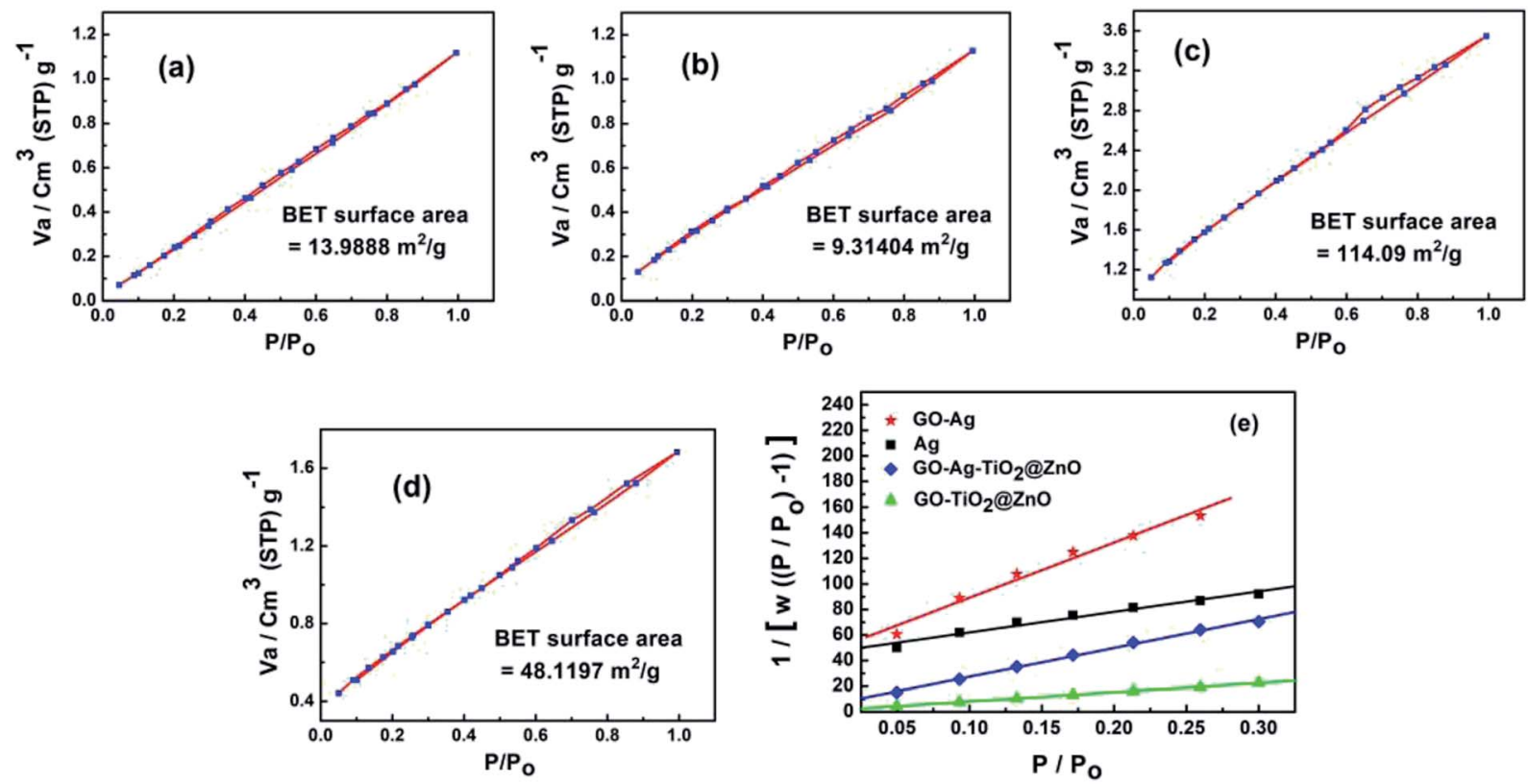

Fig. $5 \mathrm{~N}_{2}$ adsorption/desorption isotherm curve of (a) $\mathrm{Ag}$, (b) $\mathrm{GO}-\mathrm{Ag}$, (c) $\mathrm{GO}-\mathrm{TiO}_{2}\left(\mathrm{ZnO}\right.$, and (d) $\mathrm{GO}-\mathrm{Ag}-\mathrm{TiO} \mathrm{O}_{2} \mathrm{anO}$ nanocomposites. (e) Langmuir fits from the $\mathrm{N}_{2}$ adsorption data for $\mathrm{Ag}, \mathrm{GO}-\mathrm{Ag}, \mathrm{GO}-\mathrm{TiO}_{2} \mathrm{aZnO}$, and $\mathrm{GO}-\mathrm{Ag}-\mathrm{TiO}_{2} @ \mathrm{aZnO}$ nanocomposites. 


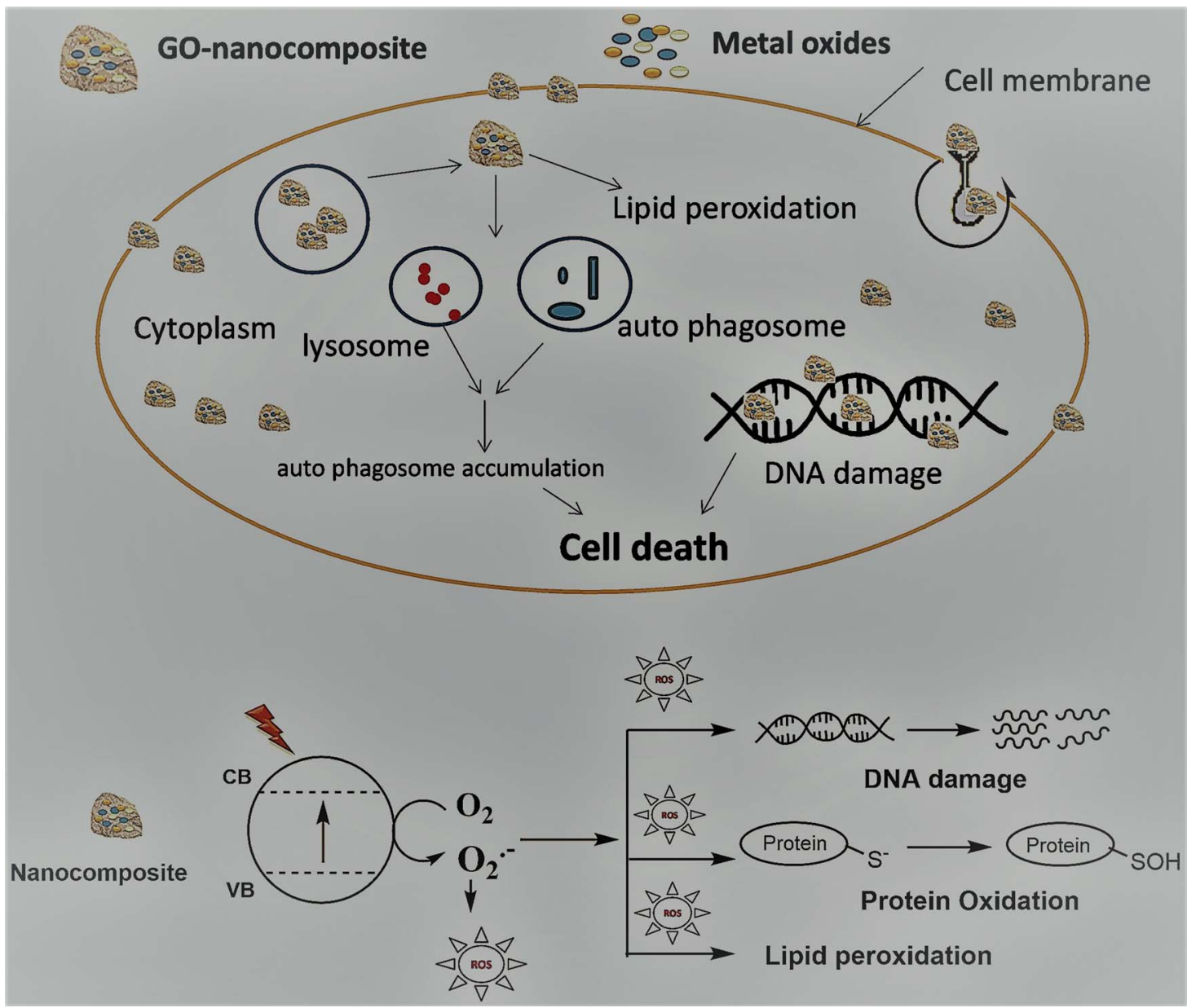

Scheme 1 Mechanism of antibacterial activity.

the energy gap. The band gap values were found to be 4.00, 2.99, 2.80, 2.62, and $2.50 \mathrm{eV}$ for $\mathrm{GO}, \mathrm{Ag}, \mathrm{GO}-\mathrm{Ag}, \mathrm{GO}-\mathrm{TiO}_{2} @ \mathrm{ZnO}$, and GO-Ag-TiO ${ }_{2} @ \mathrm{ZnO}$, respectively.

\subsection{Zeta potential analysis}

The zeta potential technique was used to assess the stability of the nanoparticles and nanocomposites in solution and to understand the charge on the surface. Fig. 3 shows that the particles are negatively charged for $\mathrm{GO}(-33 \mathrm{mV}), \mathrm{Ag}(-15 \mathrm{mV})$, GO-Ag (-31 mV), GO-TiO ${ }_{2}$ @ZnO (-29 mV), and GO-Ag$\mathrm{TiO}_{2} @ \mathrm{ZnO}(-27 \mathrm{mV})$. The negative values suggest the higher stability of colloidal dispersions of particles in water. Moreover, the zeta potential was measured at room temperature in DW as a medium. Compared with Ag NPs, the nanocomposites were highly dispersed in water, indicating the effect of GO in increasing the stability of metal oxide NPs in solution.

\subsection{FT-IR analysis}

Fig. 4 shows the FT-IR spectra of the fabricated GO, GO-Ag, GO-

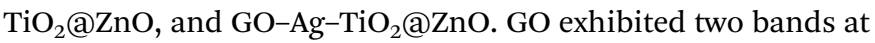
3400 and $1620 \mathrm{~cm}^{-1}$ that were assigned to the stretching vibration of the $(\mathrm{OH})$ group and the skeletal vibration of the graphene sheets, respectively. Strong peaks at 1730, 1370, 1220,
1165 , and $1058 \mathrm{~cm}^{-1}$ were assigned to the stretching vibration of oxygen-containing carboxyl $(\mathrm{C}=\mathrm{O})$, carboxyl $(\mathrm{C}-\mathrm{O})$, epoxy $(\mathrm{C}-$ $\mathrm{O})$, carboxyl $(\mathrm{C}-\mathrm{OH})$, and alkoxy $(\mathrm{C}-\mathrm{O})$ functional groups, respectively. ${ }^{67-69}$ This indicates numerous oxygen-containing functional groups over the GO surface. The characteristic peaks of $\mathrm{GO}-\mathrm{Ag}$ in the adsorption band at approximately $1629 \mathrm{~cm}^{-1}$ correspond to the $\mathrm{C}=\mathrm{C}$ bonding of the aromatic rings of the GO carbon skeleton structure. The presence of other oxygenated functional groups was observed for $\mathrm{OH}$ (at 3437 and $1427 \mathrm{~cm}^{-1}$ ), $\mathrm{C}=\mathrm{O}\left(\right.$ at $1629 \mathrm{~cm}^{-1}$ ), $\mathrm{C}-\mathrm{OH}\left(\right.$ at $1335 \mathrm{~cm}^{-1}$ ), and $\mathrm{C}-\mathrm{O}$ (at $1084 \mathrm{~cm}^{-1}$ ).

In the $\mathrm{GO}-\mathrm{Ag}$ nanocomposite, the significant decrease in the absorption bands of the oxygenated functionality could be explained by the existence of AgNPs over the surface of GO. ${ }^{70,71}$ GO-TiO ${ }_{2} @ Z n O$ usually showed characteristic absorption bands at 523 and $638 \mathrm{~cm}^{-1}$ due to two transverse optical stretching modes of $\mathrm{ZnO}$ and $\mathrm{TiO}_{2}$, respectively. The recorded band at $3435 \mathrm{~cm}^{-1}$ can be assigned to the stretching vibration of the surface hydroxyl $(-\mathrm{OH})$ groups on the surface of the metal oxide nanoparticles. These changes in functional group suggest that $\mathrm{ZnO}$ and $\mathrm{TiO}_{2}$ NPs were successfully immobilized on the surface of GO by recording the bands at 456 and $566 \mathrm{~cm}^{-1} \cdot{ }^{72,73} \mathrm{GO}-\mathrm{Ag}-$ $\mathrm{TiO}_{2} @ \mathrm{ZnO}$ nanocomposite showed characteristic peaks of $\mathrm{ZnO}$ (at $484 \mathrm{~cm}^{-1}$ ), $\mathrm{TiO}_{2} \mathrm{NPs}$ (at $584 \mathrm{~cm}^{-1}$ ), and the stretching 

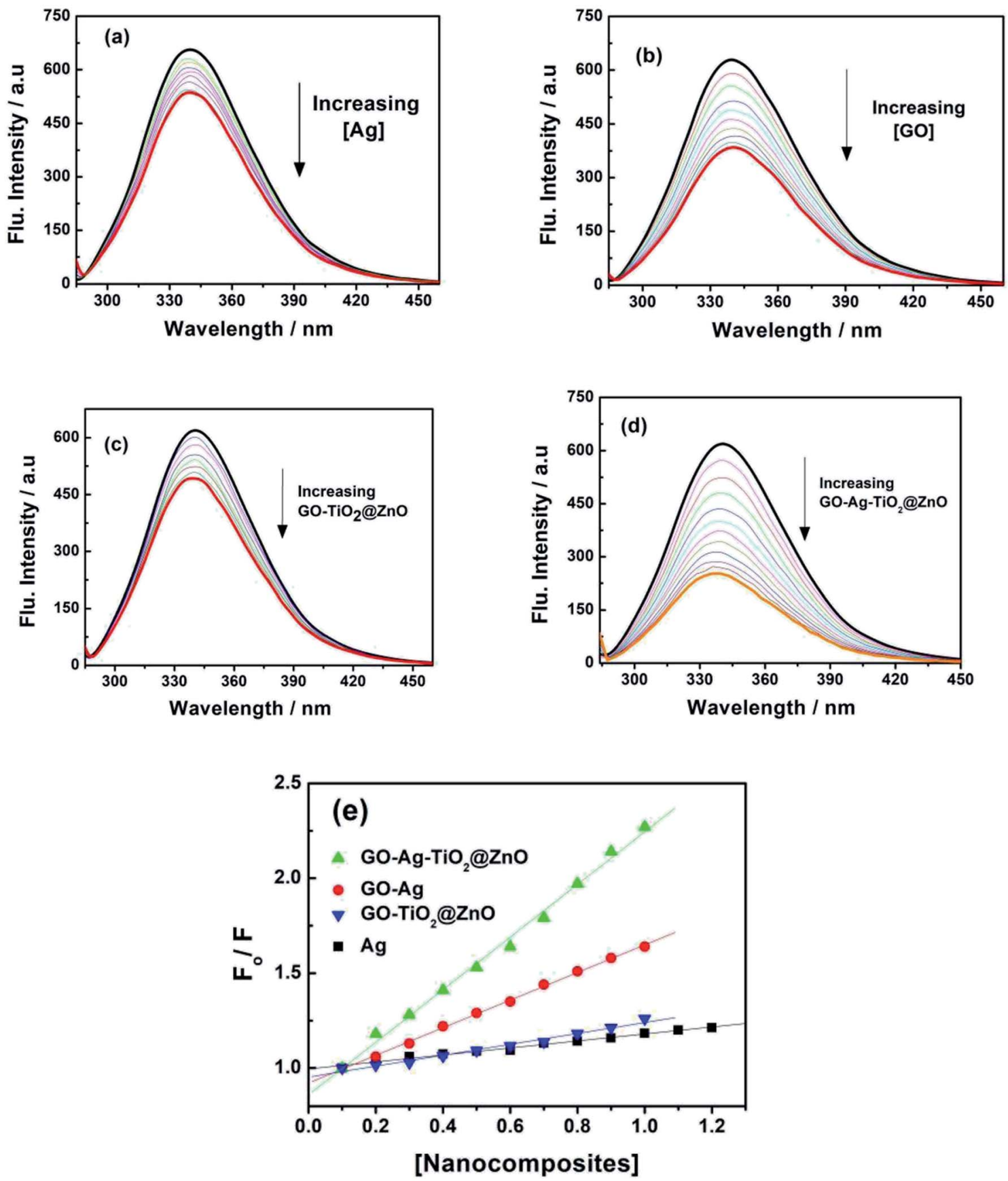

Fig. 7 Fluorescence spectra of BSA with different concentration of (a) Ag, (b) GO-Ag, (c) GO-TiO $2 @ \mathrm{ZnO}$, and (d) GO-Ag-TiO $a \mathrm{anO}$ at $\lambda_{\text {ex }}=$ $280 \mathrm{~nm}$. (e) Stern-Volmer plots.

vibration of the surface hydroxyl $(-\mathrm{OH})$ groups on the surface metal oxide nanoparticles (at $3435 \mathrm{~cm}^{-1}$ ).

\subsection{Brunauer-Emmett-Teller theory (BET) analysis}

Fig. 5 shows the surface area and pore size of the fabricated nanoparticles using the nitrogen adsorption-desorption full isotherm. The loop of isotherm was of type (IV) with a H1 hysteresis loop $\left(0.4<P / P_{0}>0.95\right)$ indicating that the surfaces of these materials have a high degree of pore size uniformity. The results illustrated that the surface has one type of pore, which is mesoporous with a diameter of 2-50 $\mathrm{nm}$. The surface area values for GO, Ag NPs, GO-Ag, GO-TiO ${ }_{2} @ \mathrm{ZnO}$ and GO-Ag$\mathrm{TiO}_{2} @ \mathrm{ZnO}$ nanocomposites were determined to be 253.87, $13.98,9.31,114.10$, and $48.12 \mathrm{~m}^{2} \mathrm{~g}^{-1}$, respectively. The average pore size was determined to be $1.223,2.238,2.315,1.898$, and $2.047 \mathrm{~nm}$ for GO, Ag, GO-Ag, GO-TiO ${ }_{2} @ \mathrm{ZnO}$, and GO-Ag$\mathrm{TiO}_{2} @ Z n O$ nanocomposites, respectively (Fig. $\mathrm{S} 2 \dagger$ ).

\subsection{Antimicrobial activity}

The fabricated GO-Ag, GO-TiO ${ }_{2} @ Z n O$, and GO-Ag-TiO ${ }_{2} @ Z n O$ $(0.005 \mathrm{~g} / 10 \mathrm{ml}$ water) nanocomposites were used to investigate their antibacterial activity against different types of bacteria that 

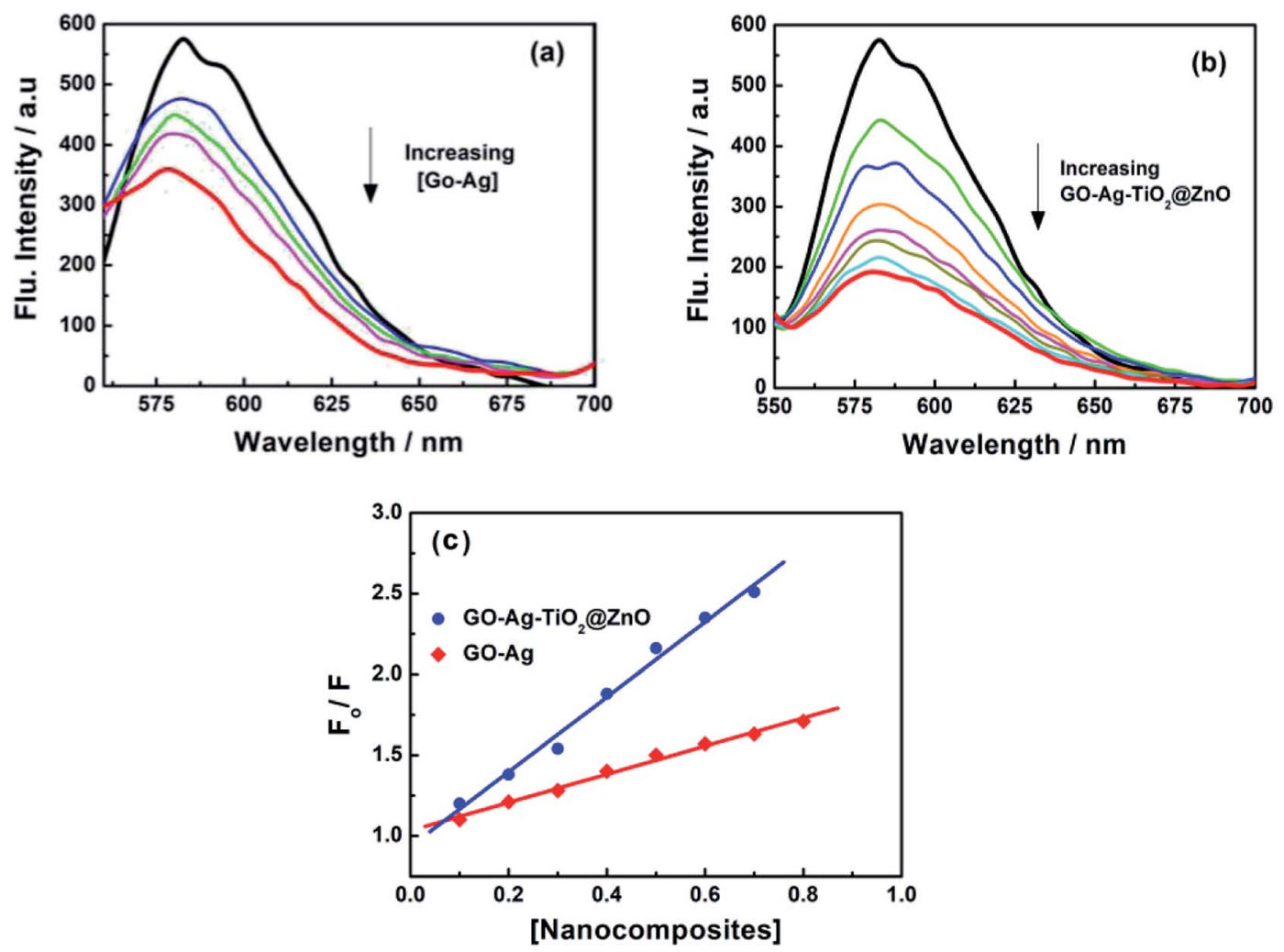

Fig. 8 Fluorescence quenching of ctDNA with different concentrations of (a) $\mathrm{GO}-\mathrm{Ag}$ and (b) $\mathrm{GO}-\mathrm{Ag}-\mathrm{TiO}{ }_{2} \mathrm{aZnO}$ in $\mathrm{Tris}-\mathrm{HCl}$ buffer; $\lambda_{\mathrm{ex}}=$ $260 \mathrm{~nm}$; (c) Stern-Volmer plots.

included strains of Gram-positive bacteria (S. aureus and $B$. anthracoides) and strains of Gram-negative bacteria (E. coli and P. multocida) by using the disc-diffusion method. The results reveal that all nanocomposites were potentially effective in suppressing bacterial growth with variable potency. GO$\mathrm{TiO}_{2} @ Z n O$ nanocomposite showed highly suppressing microbial growth against both Gram-positive and Gram-negative bacteria, but a more marked effect against Gram-negative bacteria was observed compared with Gram-positive bacteria. The Ag NPs alone had the lowest inhibitory effect on all tested bacteria. With regards to the effect of $\mathrm{GO}-\mathrm{Ag}-\mathrm{TiO}_{2} @ \mathrm{ZnO}$ and GO-Ag on tested bacteria, the obtained results showed marked suppression of this nanocomposite against Gram-negative bacteria, However, its effect on tested Gram-positive bacteria varied, in that $B$. anthracoides was more sensitive to $\mathrm{GO}-\mathrm{Ag}^{-}$ $\mathrm{TiO}_{2} @ \mathrm{ZnO}$ than $S$. aureus (Fig. 6). The overall results revealed that these nanocomposites are more effective against Gramnegative bacteria than Gram-positive bacteria. The differences in the effects of various nanoparticles on examined bacteria might be correlated with a number of factors, including type of bacteria examined, type of manufactured nanoparticle, and methodology used. The mechanism of the antibacterial effect by the fabricated nanocomposites is summarized in Scheme 1 . It is most likely that the higher antibacterial activity of the GO$\mathrm{Ag}-\mathrm{TiO}_{2} @ \mathrm{ZnO}$ nanocomposite arises from the combination between the direct damage of the cellular membranes by Ag NPs, the generation of ROS by the $\mathrm{TiO}_{2}$ and $\mathrm{ZnO}$ entities, and the accumulation of NPs in the cytoplasm. ${ }^{75-78}$

\subsection{Fluorescence quenching spectra}

To support the suggested mechanism shown in Scheme 1, the interaction between the fabricated nanocomposites and the protein and DNA was examined using fluorescence measurements. Fig. 7a-d shows the steady-state fluorescence quenching process of BSA with different concentrations of $\mathrm{Ag}, \mathrm{GO}-\mathrm{Ag}, \mathrm{GO}-$ $\mathrm{Ag}-\mathrm{TiO}_{2} @ \mathrm{ZnO}$, and $\mathrm{GO}-\mathrm{TiO}_{2} @ \mathrm{ZnO}$ nanocomposites in water. Upon excitation with $280 \mathrm{~nm}$, the emission of a BSA singlet state at $340 \mathrm{~nm}$ was considerably quenched in the presence of the examined nanocomposites. Stern-Volmer plots showed a higher quenching rate constant in the case of $\mathrm{GO}-\mathrm{Ag}^{-}$ $\mathrm{TiO}_{2} @ \mathrm{ZnO}$ compared with control nanocomposites ( $\mathrm{Ag}, \mathrm{GO}-\mathrm{Ag}$, and GO-TiO $\left.{ }_{2} @ Z n O\right)$ (Fig. 7e). ${ }^{74}$ The quenching constants of the singlet BSA in the presence of different amounts of $\mathrm{Ag}$, $\mathrm{GO}-\mathrm{Ag}$, GO-TiO ${ }_{2} @ \mathrm{ZnO}$, and $\mathrm{GO}-\mathrm{Ag}-\mathrm{TiO}_{2} @ \mathrm{ZnO}$ nanocomposites were found to be $0.18,0.73,0.28$, and $1.38 \mathrm{~min}^{-1}$, respectively. Similar observations were recorded by following the fluorescence quenching of ctDNA by adding different amounts of the examined nanocomposites in Tris-HCl buffer (Fig. 8). The quenching rate constants of the singlet ctDNA with the addition of GO-Ag and GO-Ag-TiO ${ }_{2} @ \mathrm{ZnO}$ nanocomposites were found to be 0.874 and $2.32 \mathrm{~min}^{-1}$, respectively.

\section{Conclusion}

We report herein the fabrication of promising nanocomposites, namely GO-Ag, GO-TiO ${ }_{2} @ \mathrm{ZnO}$, and GO-Ag- $\mathrm{TiO}_{2} @ \mathrm{ZnO}$. The 
fabricated nanocomposites were characterized using different analytical and spectroscopic techniques (XRD, SEM, and FT-IR). Steady-state fluorescence measurements provided clear evidence of the fluorescence quenching of BSA and ctDNA in the presence of different amounts of the fabricated nanocomposites. An antibacterial test was performed with two Grampositive and two Gram-negative bacteria. GO-TiO ${ }_{2} @ \mathrm{ZnO}$ nanocomposite was the most effective in suppressing microbial growth of the tested Gram-positive bacteria, while it had a moderate effect against Gram-negative bacteria. GO-Ag and GO-TiO ${ }_{2} @ Z n O$ nanocomposites showed strong activity against both Gram-positive and Gram-negative bacteria, and these nanocomposites are more effective against Gram-negative bacteria than Gram-positive bacteria. GO-Ag, GO-TiO ${ }_{2} @ \mathrm{ZnO}$, and $\mathrm{GO}-\mathrm{Ag}-\mathrm{TiO}_{2} @ \mathrm{ZnO}$ nanocomposites have antibacterial activity against Gram-negative and Gram-positive bacteria, with $\mathrm{Ag}$ NPs alone having the lowest inhibitory effect on all tested bacteria.

\section{Conflicts of interest}

The authors have no conflicts to declare.

\section{References}

1 M. Simões, L. Simões and M. J. Vieira, A review of current and emergent biofilm control strategies, Food Sci. Technol., 2010, 43, 573-583.

2 D. Romero and R. Kolter, Will biofilm disassembly agents make it to market, Trends Microbiol., 2011, 19, 304-306.

3 R. A. N. Chmielewski and J. F. Frank, Biofilm formation and control in food processing facilities, Compr. Rev. Food Sci. Food Saf., 2003, 2, 22-32.

4 R. V. Houdt and C. W. Michiels, Biofilm formation and the food industry, a focus on the bacterial outer surface, $J$. Appl. Microbiol., 2010, 109, 1117-1131.

5 M. E. Davey and G. A. O'Toole, Microbial biofilms: from ecology to molecular genetics, Microbiol. Mol. Biol. Rev., 2000, 64, 847-867.

6 J. B. Kaper, J. P. Nataro and H. L. Mobley, Pathogenic Escherichia coli, Nat. Rev. Microbiol., 2004, 2, 123-140.

7 C. Lozano, H. Gharsa, K. Ben Slama, M. Zarazaga and C. Torres, Staphylococcus aureus in Animals and Food: Methicillin Resistance, Prevalence and Population Structure. A Review in the African Continent, Microorganisms, 2016, 4, 12.

8 D. J. Weber, J. S. Wolfson, M. N. Swartz and D. C. Hooper, Pasteurella multocida infections. Report of 34 cases and review of the literature, Medicine, 1984, 63, 133-154.

9 A. M. Sefton, Mechanisms of antimicrobial resistance, Drugs, 2002, 62, 557-566.

10 S. A. Jassim and R. G. Limoges, Natural solution to antibiotic resistance: bacteriophages 'the living drugs', World J. Microbiol. Biotechnol., 2014, 30, 2153-2170.

11 D. Peer, J. M. Karp, S. Hong, O. C. Farokhzad, R. Margalit and R. Langer, Nanocarriers as an emerging platform for cancer therapy, Nat. Nanotechnol., 2007, 2, 751-760.
12 B. D. Brooks and A. E. Brooks, Therapeutic strategies to combat antibiotic resistance, Adv. Drug Delivery Rev., 2014, $78,14-27$.

13 A. J. Huh and Y. J. Kwon, "Nanoantibiotics": a new paradigm for treating infectious diseases using nanomaterials in the antibiotics resistant era, J. Controlled Release, 2011, 156, 128-145.

14 N. Beyth, Y. Houri-Haddad, A. Domb, W. Khan and R. Hazan, Alternative Antimicrobial Approach: Nanoantimicrobial Materials, J. Evidence-Based Complementary Altern. Med., 2015, 1-16.

15 T. Gordon, B. Perlstein, O. Houbara, I. Felner, E. Banin and S. Margel, Synthesis and characterization of zinc/iron oxide composite nanoparticles and their antibacterial properties, Colloids Surf., A, 2011, 374, 1-8.

16 S. Jadhav, S. Gaikwad, M. Nimse and A. Rajbhoj, Copper oxide nanoparticles: synthesis, characterization and their antibacterial activity, J. Cluster Sci., 2011, 22, 121-129.

17 C. Srisitthiratkul, V. Pongsorrarith and N. Intasanta, The potential use of nanosilver decorated titanium dioxide nanofibers for toxin decomposition with antimicrobial and self-cleaning properties, Appl. Surf. Sci., 2011, 257, 88508856.

18 R. M. El-Shishtawy, A. M. Asiri, N. A. Abdelwahed and M. M. Al-Otaibi, In situ production of silver nanoparticle on cotton fabric and its antimicrobial evaluation, Cellulose, 2011, 18, 75-82.

19 F. Al-Hazmi, F. Alnowaiser, A. Al-Ghamdi, A. A. Al-Ghamdi, M. Aly, R. M. Al-Tuwirqi and F. El-Tantawy, A new largescale synthesis of magnesium oxide nanowires: structural and antibacterial properties, Superlattices Microstruct., 2012, 52, 200-209.

20 Z. Zhu, M. Su, L. Ma, L. Ma, D. Liu and Z. Wang, Preparation of graphene oxide-silver nanoparticle nanohybrids with highly antibacterial capability, Talanta, 2013, 117, 449-455.

21 L. R. Martinez, G. Han, M. Chacko, M. R. Mihu, M. Jacobson, P. Gialanella, A. J. Friedman, J. D. Nosanchuk and J. M. Friedman, Antimicrobial and healing efficacy of sustained release nitric oxide nanoparticles against Staphylococcus aureus skin infection, J. Invest. Dermatol., 2009, 129, 2463-2469.

22 A. F. Faria, D. S. T. Martinez, S. M. M. Meira, A. C. M. Moraes, A. Brandelli, A. G. Filho and O. L. Alves, Anti-adhesion and antibacterial activity of silver nanoparticles supported on graphene oxide sheets, Colloids Surf., B, 2014, 113, 115-124.

23 R. Pasricha, S. Gupta and A. Srivastava, A facile and novel synthesis of Ag-graphene-based nanocomposites, Small, 2009, 20, 2253-2259.

24 X. Huang, Z. Yin, S. Wu, X. Qi, Q. He, Q. Zhang, Q. Yan, F. Boey and H. Zhang, Graphene based materials: synthesis, characterization, properties, and applications, Small, 2011, 7, 1876-1902.

25 H. Yao, L. Jin, H.-J. Sue, Y. Sumi and R. Nishimura, Facile decoration of $\mathrm{Au}$ nanoparticles on reduced graphene oxide surfaces via a one-step chemical functionalization approach, J. Mater. Chem., 2013, 1, 10783-10789. 
26 S. V. Kumar, N. M. Huang, H. N. Lim, A. Marlinda, I. Harrison and C. H. Chia, One-step size controlled synthesis of functional graphene oxide/silver nanocomposites at room temperature, Chem. Eng. J., 2013, 219, 217-224.

27 X. Cai, M. Lin, S. Tan, W. Mai, Y. Zhang, Z. Liang, Z. Lin and $\mathrm{X}$. Zhang, The use of polyethyleneimine-modified reduced graphene oxide as a substrate for silver nanoparticles to produce a material with lower cytotoxicity and long-term antibacterial activity, Carbon, 2012, 50, 3407-3415.

28 M. Rai, A. Yadav and A. Gade, Silver nanoparticles as a new generation of antimicrobials, Biotechnol. Adv., 2009, 27, 7683.

29 G. Carotenuto, G. Pepe and L. Nicolais, Preparation and characterization of nano-sized Ag/PVP composites for optical applications, Eur. Phys. J. B, 2000, 16, 11-17.

30 E. Stathatos, P. Lianos, P. Falaras and A. Siokou, Photocatalytically deposited silver nanoparticles on mesoporous $\mathrm{TiO}_{2}$ films, Langmuir, 2000, 16, 2398-2400.

31 S. V. Kyriacou, W. J. Brownlow and X.-H. N. Xu, Using nanoparticle optics assay for direct observation of the function of antimicrobial agents in single live bacterial cells, Biochemistry, 2004, 43, 140-147.

32 X. Feng, H. Ma, S. Huang, W. Pan, X. Zhang, F. Tian, C. Gao, Y. Cheng and J. Luo, Aqueous organic phase-transfer of highly stable gold, silver, and platinum nanoparticles and new route for fabrication of gold nanofilms at the oil/water interface and on solid supports, J. Phys. Chem. B, 2006, 110, 12311-12317.

33 J. Ma, J. Zhang, Z. Xiong, Y. Yong and X. Zhao, Preparation, characterization and antibacterial properties of silvermodified graphene oxide, J. Mater. Chem., 2011, 21, 33503352.

34 M. L. Knetsch and L. H. Koole, New strategies in the development of antimicrobial coatings: the example of increasing usage of silver and silver nanoparticles, Polymer, 2011, 3, 340-366.

35 K. Shameli, M. B. Ahmad, M. Zargar, W. Yunus, N. A. Ibrahim, P. Shabanzadeh and M. G. Moghaddam, Synthesis and characterization of silver/montmorillonite/ chitosan bionanocomposites by chemical reduction method and their antibacterial activity, Int. J. Nanomed., 2011, 6, 271-284.

36 C. Baker, A. Pradhan, L. Pakstis, D. J. Pochan and S. I. Shah, Synthesis and antibacterial properties of silver nanoparticles, J. Nanosci. Nanotechnol., 2005, 5, 244-249.

37 P. Khanna and V. Subbarao, Nanosized silver powder via reduction of silver nitrate by sodium formaldehyde sulfoxylate in acidic pH medium, Mater. Lett., 2003, 57, 2242-2245.

38 N. Leopold and B. Lendl, A new method for fast preparation of highly surface-enhanced Raman scattering (SERS) active silver colloids at room temperature by reduction of silver nitrate with hydroxylamine hydrochloride, J. Phys. Chem. B, 2003, 107, 5723-5727.

39 S. Liu, T. H. Zeng, M. Hofman, E. Burcombe, J. Wei, R. Jiang, J. Kong and Y. Chen, Antibacterial activity of graphite, graphene oxide, and reduced graphene oxide:membrane and oxidative stress, ACS Nano, 2011, 5, 6971-6980.

40 O. N. Ruiz, K. A. Fernando, B. Wang, N. A. Brown, P. G. Luo, N. D. McNamara, M. Vangsness, Y.-P. Sun and C. E. Bunker, Graphene oxide: a nonspecific enhancer of cellular growth, ACS Nano, 2011, 5, 8100-8107.

41 N. M. El-Shafai, M. E. El-Khouly, M. El-Kemary, M. S. Ramadan, A. S. Derballah and M. S. Masoud, Fabrication and characterization of graphene oxidetitanium dioxide nanocomposite for degradation of some toxic insecticides, J. Ind. Eng. Chem., 2019, 69, 315-323.

42 L. Liu, J. Liu, Y. Wang, X. Yan and D. D. Sun, Facile synthesis of monodispersed silver nanoparticles on graphene oxide sheets with enhanced antibacterial activity, New J. Chem., 2011, 35, 1418-1423.

43 M. R. Das, R. K. Sarma, R. Saikia, V. S. Kale, M. V. Shelke and P. Sengupta, Synthesis of silver nanoparticles in an aqueous suspension of graphene oxide sheets and its antimicrobial activity, Colloids Surf., B, 2011, 83, 16-22.

44 X. Cai, M. Lin, S. Tan, W. Mai, Y. Zhang, Z. Liang, Z. Lin and $\mathrm{X}$. Zhang, The use of polyethyleneimine-modified reduced graphene oxide as a substrate for silver nanoparticles to produce a material with lower cytotoxicity and long-term antibacterial activity, Carbon, 2012, 50, 3407-3415.

45 X. Cai, S. Tan, M. Lin, A. Xie, W. Mai, X. Zhang, Z. Lin, T. Wu and Y. Liu, Synergistic antibacterial brilliant blue/reduced graphene oxide/quaternary phosphonium salt composite with excellent water solubility and specific targeting capability, Langmuir, 2011, 27, 7828-7835.

46 X. Cai, S. Tan, A. Yu, J. Zhang, J. Liu, W. Mai and Z. Jiang, Sodium 1-naphthalenesulfonate-functionalized reduced graphene oxide stabilizes silver nanoparticles with lower cytotoxicity and long-term antibacterial activity, Chem.Asian J., 2012, 7, 1664-1670.

$47 \mathrm{~W}$. S. Hummers Jr and R. E. Offerman, Preparation of graphite oxide, J. Am. Chem. Soc., 1958, 80, 1339.

48 N. M. El-Shafai, M. E. El-Khouly, M. El-Kemary, M. S. Ramadan and M. S. Masoud, Graphene oxide-metal oxide nanocomposites: fabrication, characterization and removal of cationic rhodamine B dye, RSC Adv., 2018, 8, 13323-13332.

49 A. Bumajdad, M. Madkour, Y. Abdel-Moneam and M. ElKemary, Nanostructured mesoporous $\mathrm{Au} / \mathrm{TiO}_{2}$ for photocatalytic degradation of a textile dye: the effect of size similarity of the deposited Au with that of $\mathrm{TiO}_{2}$ pores, J. Mater. Sci., 2014, 49, 1743-1754.

50 T. Mizuno, T. Natori, I. Kanazawa, I. Eldesouky, H. Fukunaga and T. Ezaki, Core housekeeping proteins useful for identification and classification of mycobacteria, Microb. Resour. Syst., 2016, 32, 25-37.

51 I. E. Eldesouky, M. A. Refae, H. S. Nada and G. R. Hassb Elnaby, Molecular Detection of Streptococcus Species Isolated from Cows with Mastitis, World Vet. J., 2016, 6, 193-202.

52 I. E. Eldesouky, M. O. Eissa, H. S. Nada and A. M. Abdel Satar, Molecular characterization of Salmonella species 
isolated from some meat products, J. Nat. Sci., 2016, 14, 8389.

53 M. M. Shahid, P. Rameshkumar, W. J. Basirun, J. J. Ching and N. M. Huang, Cobalt oxide nanocubes interleaved reduced graphene oxide as an efficient electrocatalyst for oxygen reduction reaction in alkaline medium, Electrochim. Acta, 2017, 237, 61-68.

54 B. Ouadila, O. Cherkaoui, M. Safi and M. Zahouily, Surface modification of knit polyester fabric for mechanical, electrical and UV protection properties by coating with graphene oxide, graphene and graphene/silver nanocomposites, Appl. Surf. Sci., 2017, 414, 292-302.

55 G. Bagherzade, M. M. Tavakoli and M. H. Namaei, Green synthesis of silver nanoparticles using aqueous extract of saffron (Crocus sativus L.) wastages and its antibacterial activity against six bacteria, Asian Pac. J. Trop. Biomed., 2017, 7, 227-233.

56 K. Jyoti, M. Baunthiyal and A. Singh, Characterization of silver nanoparticles synthesized using Urtica dioica Linn. leaves and their synergistic effects with antibiotics, $J$. Radiat. Res. Appl. Sci., 2016, 9, 217-227.

$57 \mathrm{~J}$. Li and C. Liu, Ag-graphene heterostructures: synthesis, characterization and optical properties, Eur. J. Inorg. Chem., 2010, 1244-1248.

58 X. Zhou, X. Huang, X. Qi, S. Wu, C. Xue, F. Y. C. Boey, Q. Yan, P. Chen and H. Zhang, In situ synthesis of metal nanoparticles on single-layer graphene oxide and reduced graphene oxide surfaces, J. Phys. Chem. C, 2009, 113, 10842-10846.

59 P. Senthil Kumar, M. Selvakumar, S. Ganesh Babu, S. Induja and S. Karuthapandian, $\mathrm{CuO} / \mathrm{ZnO}$ nanorods: an affordable efficient $\mathrm{p}-\mathrm{n}$ heterojunction and morphology dependent photocatalytic activity against organic contaminants, $J$. Alloys Compd., 2017, 701, 562-573.

60 H. Shang, D. Han, M. Ma, S. Li, W. Xue and A. Zhang, Enhancement of the photo killing effect of $\mathrm{TiO}_{2}$ in photodynamic therapy by conjugating with reduced graphene oxide and its mechanism exploration, $J$. Photochem. Photobiol., B, 2017, 177, 112-123.

61 S. Woo, Y.-R. Kim, T. D. Chung, Y. Piao and H. Kim, Synthesis of a graphene-carbon nanotube composite and its electrochemical sensing of hydrogen peroxide, Electrochim. Acta, 2012, 59, 509-514.

62 D. Li, M. B. Müller, S. Cilije, R. B. Kanar and G. G. Wallace, Processable aqueous dispersions of graphene nanosheets, Nat. Nanotechnol., 2008, 3, 101-105.

63 D. D. Evanoff and G. Chumanov, Synthesis and optical properties of silver nanoparticles and arrays, ChemPhysChem, 2005, 6, 1221-1231.

64 M. El-Kemary, N. Nagy and I. El-Mehasseb, Nickel oxide nanoparticles: synthesis and spectral studies of inter actions with glucose, Mater. Sci. Semicond. Process., 2013, 16, 1747-1752.
65 R. Lopez and R. Gomez, Band-gap energy estimation from diffuse reflectance measurements on sol-gel and commercial $\mathrm{TiO}_{2}$ : a comparative study, J. Sol-Gel Sci. Technol., 2012, 61, 1-7.

66 A. Hagfeldt and M. Gratzel, Light-induced reactions in nanocrystalline systems, Chem. Rev., 1995, 95, 49-68.

67 D. Liang, C. Cui, H. Hu, Y. Wang, S. Xu, B. Ying, P. Li, B. Lu and $H$. Shen, One-step hydrothermal synthesis of anatase $\mathrm{TiO}_{2} /$ reduced graphene oxide nanocomposites photocatalytic activity, J. Alloys Compd., 2014, 582, $236 \mathrm{e} 240$.

68 X. Pan, Y. Zhao, S. Liu, C. L. Korzeniewski, S. Wang and Z. Fan, Comparing graphene- $\mathrm{TiO}_{2}$ nanowire and graphene$\mathrm{TiO}_{2}$ nanoparticle composite photocatalysts, ACS Appl. Mater. Interfaces, 2012, 4, 3944-3950.

69 H. M. Yadav and J.-S. Kim, Solvothermal synthesis of anatase $\mathrm{TiO}_{2}$-graphene oxide nanocomposites and their photocatalytic performance, J. Alloys Compd., 2016, 688, 123-129.

70 C. Zhu, S. Guo, Y. Fang and S. Dong, Reducing sugar: new functional molecules for the green synthesis of graphene nanosheets, ACS Nano, 2010, 4, 2429-2437.

71 S. Zakaria, M. K. Ayob, K. L. Chee, N. M. Huang, H. M. Neoh, H. N. Lim, R. Jamal and R. M. F. R. Abdul Rahman, Antibacterial performance of $\mathrm{Ag}$ nanoparticles and AgGO nanocomposites prepared via rapid microwave-assisted synthesis method, Nanoscale Res. Lett., 2012, 7, 541.

72 A. R. Chowdhuri, S. Tripathy, S. Chandra, S. Roy and S. K. Sahu, A ZnO decorated chitosan-graphene oxide nanocomposite shows significantly enhanced antimicrobial activity with ROS generation, RSC Adv., 2015, 5, 49420-49428.

73 S. D. Delekar, H. M. Yadav, S. N. Achary, S. S. Meena and S. H. Pawar, Structural refinement and photocatalytic activity of Fe-doped anatase $\mathrm{TiO}_{2}$ nanoparticles, Appl. Surf. Sci., 2012, 263, 536-545.

74 O. Stern and M. Volmer, Z. Phys., 1919, 20, 183-188.

75 Z. Zhu, M. Su, L. Ma, L. Ma, D. Liu and Z. Wang, Preparation of graphene oxide-silver nanoparticle nanohybrids with highly antibacterial capability, Talanta, 2013, 117, 449-455.

76 X. Cai, S. Tan, M. Lin, A. Xie, W. Mai, X. Zhang, Z. Lin, T. Wu and Y. Liu, Synergistic antibacterial brilliant blue/reduced graphene oxide/quaternary phosphonium salt composite with excellent water solubility and specific targeting capability, Langmuir, 2011, 27, 7828-7835.

$77 \mathrm{~S}$. Ghosh and A. Das, Modified titanium oxide $\left(\mathrm{TiO}_{2}\right)$ nanocomposites and its array of applications: a review, Toxicol. Environ. Chem., 2015, 1-43.

78 H. Yang, C. Liu, D. Yang, H. Zhang and Z. Xi, Comparative study of cytotoxicity, oxidative stress and genotoxicity induced by four typical nanomaterials: the role of particle size, shape and composition, J. Appl. Toxicol., 2009, 29, 6978. 